\title{
Efek Perbedaan Sumber Protein dan Rasio Urea-Molases dalam Pakan Suplemen yang Ditambahkan dalam Ransum Terhadap Produksi Mikrobia Rumen Secara In Vitro
}

\author{
S. D. WIDYAWATI \\ Jurusan Peternakan, Fakultas Pertanian, Universitas Sebelas Maret \\ Jl. Ir. Sutami 36 A, Kentingan, Surakarta \\ Email: susidwiwidyawati@yahoo.co.id
}

\section{INTISARI}

Penelitian bertujuan untuk mengetahui pengaruh penambahan bahan pakan sumber protein (bungkil kedelai dan daun lamtoro) yang disusun dalam pakan suplemen terhadap sintesis mikrobia rumen yang tercermin dari proses fermentasi dan produksi $\mathrm{N}$ mikrobia rumen secara in vitro. Penelitian ini dilaksanakan di Laboratorium Ilmu Nutrisi dan Makanan Ternak, Fakultas Pertanian UNS dan Laboratorium Biokimia Nutrisi, Fakultas Peternakan UGM, selama 10 bulan. Rumput lapangan sebagai ransum basal dan pakan suplemen disusun dengan komposisi yang berbeda, urea : molases $=1: 5$, 1:6, 1:7, bungkil kedelai (BK) dan daun lamtoro (DL). Adapun susunan ke 6 perlakuan yang diterapkan adalah T1(BK-UM1:5), T2 (DL-UM1:5) T3(BK-UM1:6), T4 (DLUM1:6) T5(BK-UM1:7), T6 (DL-UM1:7). Penelitian ini dilakukan dengan metode in vitro gas test (Menke dan Steingass, 1979), sumber inokulum yang digunakan diambil dari sapi berfistula rumen. Pengambilan cairan rumen dilakukan sebelum pakan pagi hari didistribusikan.

Derajat keasaman $(\mathrm{pH})$ cairan rumen, berturut-turut 6,$87 ; 6,81 ; 6,79 ; 6,80 ; 6,82$ dan 6,81 . pH ini berada pada kondisi normal untuk terjadinya fermentasi mikrobial yang optimal. Proses fermentasi mikrobial berjalan dengan baik sehingga produksi VFA nya pun cukup baik, berturut-turut, 100,82; 98,85; 92,49;102,66;100,14 dan 84,68 mM. Hasil yang diperoleh untuk $\mathrm{C}_{2}$ adalah 67,$84 ; 71,17 ; 62,50 ; 66,34 ; 65,86$ dan $57,84 \mathrm{mM}$. Sedangkan produksi $\mathrm{C}_{3}$, berturut-turut 22,$66 ; 21,71 ; 20,08 ; 26,62 ; 24,08$ dan 19,42 mM. Namun rasio $\mathrm{C}_{2} / \mathrm{C}_{3}$ nyata $(\mathrm{P}<0,05)$ dipengaruhi oleh perlakuan. Perbedaan yang nyata terjadi pada rasio urea : malases $=1: 6$, bahwa penggunaan $\mathrm{BK}$ dan $\mathrm{DL}$ nyata $(\mathrm{P}<0,05)$ mengubah rasio $\mathrm{C}_{2} / \mathrm{C}_{3}$. Tinggi rendahnya $\mathrm{NH}_{3}$ ini menunjukkan sifat solubilitas protein dalam pakan dan optimalisasi sintesis mikrobia rumen. Konsentrasi $\mathrm{NH}_{3}$ yang dihasilkan berturut-turut 26,19; 25,41; 27,05; 25,54; 26,55 dan 25,78 $\mathrm{mg} / 100 \mathrm{ml}$..Produksi $\mathrm{N}$ mikrobia yang tertinggi $(5,28 \mathrm{mg} / 100 \mathrm{ml})$ dicapai oleh T5 (BKUM1:7) dan sangat nyata $(\mathrm{P}<0.01)$ dibandingkan dengan perlakuan yang lain. Sehingga pada tingkat produksi VFA dan konsentrasi $\mathrm{NH}_{3}$ yang setara, ternyata terjadi perbedaan pada produksi $\mathrm{N}$ mikrobia. Jadi produksi $\mathrm{N}$ mikrobia lebih ditentukan oleh sinkronisasi penyediaan energi (VFA) dan sumber $\mathrm{N}\left(\mathrm{NH}_{3}\right)$.

Kesimpulan yang dapat diambil dari penelitian ini bahwa produksi $\mathrm{N}$ mikrobia yang optimal dicapai oleh ransum (rumput lapangan) yang ditambah dengan pakan suplemen yang mengandung bungkil kedelai dengan rasio urea : molasses $=1: 7$.

Kata kunci : rumput lapangan, bungkil kedelai, daun lamtoro, suplemen, produksi $\mathrm{N}$ mikrobia 


\section{PENDAHULUAN}

Perbaikan kualitas pakan serat, seperti rumput-rumputan maupun limbah pertanian, dapat dilakukan melalui teknologi pengolahan pakan, baik secara kimiawi maupun biologi. Telah banyak cara dilakukan untuk memperbaiki kualitas pakan serat, antara lain dengan penambahan urea pada proses amoniasi atau penambahan $\mathrm{NaOH}$. Sedangkan secara biologi biasa dikerjakan dengan proses fermentasi menggunakan bakteri atau kapang yang sesuai dengan substratnya. Upaya tersebut di atas sering terkendala aplikasinya pada masyarakat pengguna teknologi itu. Kesulitan proses pembuatannya maupun pengadaan kapang atau bakteri pada proses fermentasi.

Tujuan utama yang ingin dicapai adalah peningkatan nilai cerna pakan serat. Untuk mencapai tujuan ini, maka satu hal yang harus diperhatikan adalah peran mikrobia rumen yang sangat besar pada proses pencernaan fermentatif dalam rumen. Teknologi di atas dilakukan untuk mempermudah peran mikrobia dalam mencerna pakan serat. Dengan kendala yang ada, maka salah satu teknologi yang memungkinkan untuk dapat dikerjakan adalah teknologi suplementasi.

Suplementasi nutrien dalam upaya memperbaiki dan mengoptimalkan biofermentasi dalam rumen dapat dilakukan dengan membuat kondisi rumen yang optimal untuk tumbuh dan berkembangnya mikrobia rumen dan menyediakan nutrien yang esensial dibutuhkan oleh mikrobia. Nutrien esensial yang dibutuhkan mikrobia adalah ketersediaan energi (molases) dan senyawa Nitrogen (urea) yang bersamaan, artinya kedua bahan pakan yang digunakan mempunyai degradabilitas yang setara sehingga dapat menyediakan nutrien secara bersama-sama pada saat mikrobia membutuhkan. Selain itu secara kuantitas haruslah dipenuhi sehingga perlu aras atau tingkat yang berbeda untuk mencari optimalisasi penggunaan sumber energi dan sumber N. Kebutuhan protein asal mikrobia menempati sekitar 60 sampai $80 \%$ dari total kebutuhan protein ternak. Selebihnya dapat dipenuhi dari protein pakan yang lolos dari degradasi oleh mikrobia rumen (bypass protein). Banyak sekali bahan pakan yang mempunyai kandungan protein yang secara alami bersifat tahan degradasi dan ada yang dapat diupayakan supaya protein yang terkandung di dalam bahan pakan dapat lolos degradasi. Bungkil kedelai dan daun lamtoro merupakan contoh bahan pakan yang mengandung bypass protein.

Berdasarkan kajian di atas, maka teknologi suplementasi nutrien yang dapat memperbaiki lingkungan rumen dan mengoptimalkan aktifitas mikrobia rumen merupakan upaya yang cukup strategis dan perlu dikaji dalam penelitian ini.

\section{MATERI DAN METODE}

Penelitian ini dilaksanakan di Laboratorium Ilmu Nutrisi dan Makanan Ternak, Fakultas Pertanian UNS dan Laboratorium Biokimia Nutrisi, Fakultas Peternakan UGM, selama 10 bulan pada bulan Februari hingga Desember 2006.

Rumput lapangan sebagai ransum basal dan pakan suplemen disusun dengan komposisi yang berbeda, urea : molasses $=1: 5,1: 6,1: 7$, bungkil kedelai (BK) dan daun lamtoro (DL) serta mengandung minyak ikan lemuru. Adapun susunan ke 6 perlakuan yang diterapkan adalah : 1) T1 (BK-UM15) = rumput lapang + pakan suplemen yang mengandung $\mathrm{BK}$ dan $\mathrm{U}: \mathrm{M}=1: 5$; 2) $\mathrm{T} 2$ $($ BK-UM15) $=$ rumput lapang + pakan suplemen yang mengandung DL dan U:M $=1: 5$; 3) $\mathrm{T} 3$ (BK-UM16) = rumput lapang + pakan suplemen yang mengandung $\mathrm{BK}$ dan $\mathrm{U}: \mathrm{M}=1: 6$; 4) $\mathrm{T} 4$ 
$($ BK-UM16) $=$ rumput lapang + pakan suplemen yang mengandung DL dan U:M $=1: 6$; 5) $\mathrm{T} 5$ (BK-UM17) = rumput lapang + pakan suplemen yang mengandung $\mathrm{BK}$ dan $\mathrm{U}: \mathrm{M}=1: 7$; dan 6) T6 $($ BK-UM17) $=$ rumput lapang + pakan suplemen yang mengandung DL dan U:M $=1:$ 7. Kandungan nutrien pakan suplemen yang digunakan pada penelitian ini disajikan pada tabel di bawah ini. Analisis kandungan nutrien ini dikerjakan dengan mengikuti petunjuk AOAC (1981).
Penelitian ini dilakukan dengan metode Invitro gas test (Menke dan Steingas, 1979), sumber inokulum yang digunakan diambil dari sapi berfistula rumen.

Derajat keasaman $(\mathrm{pH})$ diukur dengan menggunakan $\mathrm{pH}$ meter, produksi VFA parsial dan total dianalisis dengan menggunakan GC (Gas Chromatography), konsentrasi amonia diukur dengan menggunakan spectrophotometer dan produksi $\mathrm{N}$ mikrobia menggunakan metode Lowry (Anonimous, 2004).

Tabel 1. Kandungan nutrien pakan suplemen (\%)

\begin{tabular}{lccccccc}
\hline \hline \multirow{2}{*}{ Nutrien } & $\begin{array}{c}\text { T1 (BK- } \\
\text { UM15) }\end{array}$ & $\begin{array}{c}\text { T2 (BK- } \\
\text { UM15) }\end{array}$ & $\begin{array}{c}\text { T3 (BK- } \\
\text { UM16) }\end{array}$ & $\begin{array}{c}\text { T4 (BK- } \\
\text { UM16) }\end{array}$ & $\begin{array}{c}\text { T5 (BK- } \\
\text { UM17) }\end{array}$ & $\begin{array}{c}\text { T6 (BK- } \\
\text { UM17) }\end{array}$ & RL \\
\hline BK & 86,22 & 60,65 & 86,24 & 79,90 & 86,40 & 79,08 & 94,47 \\
PK & 28,33 & 26,83 & 28,68 & 25,80 & 28,54 & 26,35 & 12,26 \\
LK & 7,72 & 5,57 & 6,81 & 5,23 & 6,69 & 4,12 & 2,22 \\
SK & 7,80 & 6,65 & 4,81 & 5,71 & 8,67 & 6,51 & 16,58 \\
Abu & 15,74 & 9,27 & 10,11 & 11,65 & 9,41 & 9,80 & 11,92 \\
TDN* & 76,24 & 75,82 & 80,77 & 75,89 & 75,73 & 74,04 & 61,24 \\
\hline
\end{tabular}

Keterangan : *) TDN diduga dengan persamaan : TDN $=59,68-1,08 \mathrm{SK}+0,3136 \mathrm{PK}$ $+1,22 \mathrm{~L}+$ 0,2508BETN (Sutardi, 1991)

\section{HASIL DAN PEMBAHASAN}

Respon yang diukur selama penelitian dapat dilihat pada tabel di bawah ini. Pengukuran derajat keasaman sebagai indikator keberhasilan teknologi suplementasi dalam mempertahankan kondisi lingkungan rumen. $\mathrm{pH}$ optimal untuk terjadinya fermentasi pakan serat oleh mikrobia selulolitik adalah $6.2-6.8$. Produksi VFA merupakan produk akhir pencernaan mikrobial terhadap karbohidrat, sehingga VFA mencerminkan potensi karbohidrat dalam proses pencernaan dan akhirnya menyediakan komponen sumber energi.

Konsentrasi $\mathrm{N}^{-\mathrm{NH}_{3}}$ digunakan sebagai tolok ukur solubilitas protein yang terdegradasi oleh mikrobia rumen. Protein pakan yang masuk ke dalam rumen sebagian dihidrolisis menjadi peptida dan asam-asam amino oleh mikrobia rumen. Besar kecilnya degradasi dalam rumen tergantung dari asal protein yang menunjukkan karakteristik fisiko-kemis, aktivitas mikrobia rumen (Widyobroto, et al, 1997).

Derajat keasaman $(\mathrm{pH})$ cairan rumen, berturut-turut $6.87,6.81,6.79$, $6.80,6.82$ dan 6.81. $\mathrm{pH}$ ini berada pada kondisi normal untuk terjadinya fermentasi mikrobial yang optimal. $\mathrm{pH}$ cairan rumen yang dihasilkan dalam penelitian ini tidak dipengaruhi oleh pakan suplemen yang diberikan dalam ransum basal rumput lapangan. Perbedaan pakan sumber protein dan rasio urea : molases sebagai komponen pakan suplemen tidak menunjukkan adanya perubahan kondisi lingkungan dalam rumen. 
Tabel 2. Respon Yang Dimati Selama Penelitian

\begin{tabular}{|c|c|c|c|c|c|c|}
\hline Peubah & $\overline{\mathrm{T} 1}$ & T2 & T3 & $\overline{\mathrm{T} 4}$ & T5 & T6 \\
\hline $\mathrm{pH}$ & $6,87^{\mathrm{a}}$ & $6,81^{\mathrm{a}}$ & $6,79^{\mathrm{a}}$ & $6,80^{\mathrm{a}}$ & $6,82^{\mathrm{a}}$ & $6,81^{\mathrm{a}}$ \\
\hline Produksi VFA (mM) & $100,82^{\mathrm{a}}$ & $98,85^{\mathrm{a}}$ & $92,49^{\mathrm{a}}$ & $102,66^{\mathrm{a}}$ & $100,14^{\mathrm{a}}$ & $84,68^{\mathrm{a}}$ \\
\hline - $\mathrm{C} 2$ & $67,84^{\mathrm{a}}$ & $71,17^{\mathrm{a}}$ & $62,50^{\mathrm{a}}$ & $66,34^{\mathrm{a}}$ & $65,86^{\mathrm{a}}$ & $57,84^{\mathrm{a}}$ \\
\hline - $\mathrm{C} 3$ & $22,66^{\mathrm{a}}$ & $21,71^{\mathrm{a}}$ & $20,08^{\mathrm{a}}$ & $26,62^{\mathrm{a}}$ & $24,08^{\mathrm{a}}$ & $19,42^{\mathrm{a}}$ \\
\hline - $\mathrm{C} 4$ & $10,32^{\mathrm{b}}$ & $9,40^{\mathrm{b}}$ & $9,92^{b}$ & $9,70^{\mathrm{b}}$ & $10,20^{\mathrm{b}}$ & $9,42^{\mathrm{a}}$ \\
\hline - $\mathrm{C} 2 / \mathrm{C} 3$ & $2,99^{\mathrm{ab}}$ & $3,17^{\mathrm{b}}$ & $3,11^{\mathrm{b}}$ & $2,51^{\mathrm{a}}$ & $2,75^{\mathrm{ab}}$ & $3,04^{\mathrm{ab}}$ \\
\hline $\begin{array}{l}\text { Konsentrasi N-NH } \\
(\mathrm{mg} / 100 \mathrm{ml})\end{array}$ & $26,19^{a}$ & $25,41^{\mathrm{a}}$ & $27,05^{\mathrm{a}}$ & $25,54^{\mathrm{a}}$ & $26,55^{\mathrm{a}}$ & $25,78^{\mathrm{a}}$ \\
\hline $\begin{array}{l}\text { Produksi N mikrobia } \\
(\mathrm{mg} / 100 \mathrm{ml})\end{array}$ & $2,96^{\mathrm{AB}}$ & $2,58^{\mathrm{A}}$ & $2,45^{\mathrm{A}}$ & $3,17^{\mathrm{B}}$ & $5,28^{\mathrm{C}}$ & $3,17^{\mathrm{B}}$ \\
\hline
\end{tabular}

Keterangan : a,b Nilai rataan yang bersuperskrip huruf kecil yang berbeda pada baris yang sama menunjukkan bedaan nyata $(\mathrm{P}<0,05)$

A, B, C Nilai rataan yang bersuperskrip huruf besar yang berbeda pada baris yang sama menunjukkan bedaan sangat nyata $(\mathrm{P}<0,01)$

Kondisi lingkungan rumen mempunyai hubungan yang erat dengan $\mathrm{pH}$ cairan rumen, karena tinggi rendahnya $\mathrm{pH}$ di rumen akan berpengaruh terhadap aktivitas mikrobia rumen (Soebarinoto et al., 1991). Selanjutnya dikatakan oleh Owens dan Goestch (1988), bahwa aktivitas mikrobia sangat sensitif terhadap perubahan $\mathrm{pH}$ sehingga akan berpengaruh terhadap perkembangan populasi mikrobia. Perubahan $\mathrm{pH}$ yang terjadi dalam rumen dipengaruhi oleh jenis pakan yang diberikan. Ternak yang mengkonsumsi pakan banyak mengandung karbohidrat, di dalam rumen produk fermentasi VFA akan meningkat (Faria dan Huber, 1984). Meningkatnya produksi VFA di dalam rumen menyebabkan penurunan $\mathrm{pH}$ cairan rumen (Kerley et al., 1987) dan pH yang rendah ini menyebabkan kondisi rumen lebih asam sehingga terjadi penurunan aktivitas mikrobia yang tahan terhadap $\mathrm{pH}$ rendah, seperti bakteri selulolitik dan hemiselulolitik. Populasi serta aktivitas bakteri tersebut akan terhambat apabila $\mathrm{pH}$ rumen lebih rendah dari 6,0 dan sebagai akibatnya degradasi pakan berserat akan menurun (Owens dan Goestch, 1988; Lechner-Doll et al., 1995), sebagai contoh degradasi selulosa menurun sekitar $20-55 \%$ (Grovum, 1988). Enzim selulolitik akan aktif pada pH 6,2 - 7, hal ini terjadi pada saat ternak banyak mengkonsumsi pakan berserat (Pitt et al., 1996).

Proses fermentasi mikrobial berjalan dengan baik pada $\mathrm{pH}$ yang normal, sehingga produksi VFA nya pun cukup baik. Produksi VFA menunjukkan tinggi rendahnya bahan-bahan yang berpotensi terdegradasi dalam rumen dari ransum perlakuan. Nilai yang diperoleh berturut-turut, 100.82, 98.85, 92.49, 102.66, 100.14 dan $84.68 \mathrm{mM}$. Perbedaan komposisi bahan pakan dalam pakan suplemen tidak memberikan perbedaan terhadap produksi VFA. Keadaan ini menunjukkan indikasi bahwa perbandingan urea dan molases yang berbeda $(1: 5,1: 6$ dan $1: 7)$ tidak memberikan perbedaan produksi VFA, sehingga dapat dikatakan bahwa urea sebagai sumber $\mathrm{N}$ dan molases sebagai sumber energi memberikan pasokan nutrien yang cukup untuk tumbuh kembangnya mikrobia rumen. Rasio urea : molases yang meningkat pada pakan suplemen tidak terlihat meningkatkan potensi karbohidrat tercerna, hasil ini didukung oleh pendapat Kerley et al. (1987). 
Hasil yang diperoleh untuk $\mathrm{C}_{2}$ adalah $67.84,71.17,62.50,66.34,65.86$ dan $57.84 \mathrm{mM}$. Sedangkan produksi $\mathrm{C}_{3}$, berturut-turut 22.66, 21.71, 20.08, 26.62, 24.08 dan $19.42 \mathrm{mM}$. Namun rasio $\mathrm{C}_{2} / \mathrm{C}_{3}$ nyata $\quad(\mathrm{P}<0.05) \quad$ dipengaruhi oleh perlakuan pemberian pakan suplemen. Perbedaan yang nyata terjadi pada rasio urea : malases $=1: 6$, bahwa penggunaan BK dan $\mathrm{DL}$ nyata $(\mathrm{P}<0.05)$ mengubah rasio $\mathrm{C}_{2} / \mathrm{C}_{3}$. Daun lamtoro sebagai sumber protein dalam pakan suplemen dengan rasio urea : molases, $1: 6$ memperlihatkan adanya perubahan pola fermentasi dalam rumen. Menurunnya nisbah $\mathrm{C} 2 / \mathrm{C} 3 \quad$ sebagai akibat meningkatnya produksi C3 dan menurunnya produksi $\mathrm{C} 2$, walaupun secara statistik kedua komponen VFA tersebut tidak menunjukkan adanya perbedaan yang nyata. Keadaan ini menunjukkan adanya efek asosiasi antar bahan pakan (Tillman et al., 1986) yang berbeda pada tingkat penggunaan urea dan molases, $1: 6$.

Konsentrasi $\mathrm{NH}_{3}$ menggambarkan protein pakan yang terdegradasi di dalam rumen. Tinggi rendahnya $\mathrm{NH}_{3}$ ini menunjukkan sifat solubilitas protein dalam pakan dan optimalisasi sintesis mikrobia rumen. Konsentrasi $\mathrm{NH}_{3}$ yang dihasilkan berturut-turut $26.19,25.41$, $27.05,25.54,26.55$ dan $25.78 \mathrm{mg} / 100 \mathrm{ml}$. Keadaan ini cukup optimal untuk pertumbuhan dan perkembangan mikrobia rumen serta beraktivitas. Konsentrasi amonia di dalam rumen dipengaruhi oleh beberapa faktor antara lain solubilitas dan laju degradasi protein pakan (Sauvant, 1995; Widyobroto et al., 1995), level Nitrogen dalam ransum, waktu pengosongan rumen, laju penggunaan Nitrogen oleh biomass mikrobia rumen dan absorpsi amonia (Djajanegara, 1983). Apabila pakan rendah kandungan proteinnya atau protein yang terkandung tahan terhadap degradasi mikrobia rumen, maka konsentrasi amonia rumen rendah dan pertumbuhan mikrobia rumen lambat, akibatnya degradasi karbohidrat akan terhambat (McDonald et al., 1988). Konsentrasi $\mathrm{NH}_{3}$ cairan rumen bervariasi antara 1 $34 \mathrm{mg} / 100 \mathrm{ml}$ (Leng, 1980). Maksimum laju sintesis protein mikrobia akan tercapai jika konsentrasi $\mathrm{NH}_{3}$ berkisar antara 5,0 - 8,0 mg/100 ml (Satter dan Slyter, 1974). Asam-asam amino mengalami degradasi lebih lanjut dan deaminasi menjadi VFA, $\mathrm{NH}_{3}$ dan $\mathrm{CO}_{2}$ (Ørskov, 1992).

Konsentrasi amonia mempunyai kisaran yang cukup luas, sebagaimana dikemukakan oleh Satter dan Slyter, (1974), Orskov (1992) dan Sutardi (1978). Selanjutnya Sutardi (1979) dalam laporannya menjelaskan bahwa konsentrasi $\mathrm{NH}_{3}$ hingga $93.8 \mathrm{mg} / 100 \mathrm{ml}$ cairan tidak menunjukkan adanya peningkatan sintesis mikrobia rumen. Sementara Erwanto et al., (1993) menjelaskan bahwa kadar amonia sebesar 7 sampai $8 \mathrm{mM}$ dianggap cukup untuk mencapai efisiensi penggunaan energi dan protein ransum. Jika ditinjau dari fase pertumbuhan mikrobia, maka pada lag phase menunjukkan persiapan mikrobia untuk bertumbuh, kemudian diikuti dengan log phase, disini mikrobia mulai bertumbuh untuk mencapai tahap maksimal selanjutnya tidak ada tidak terjadi pertumbuhan pada phase stationary, mikrobia berusaha untuk mempertahankan hidupnya, kemudian diikuti dengan death phase atau fase kematian.

Mekanisme degradasi protein di dalam rumen berlangsung secara bertahap, yaitu protein akan mengalami hidrolisis menjadi peptide oleh enzim proteolitik yang dihasilkan oleh mikrobia. Sebagian peptide digunakan untuk sintesis protein tubuh mikrobia, dan sebagian lagi didegradasi menjadi asam amino (McDonald et al., 1988), dan selanjutnya asam amino akan mengalami deaminasi 
menjadi $\mathrm{NH}_{3}$, asam alfa-keto dan $\mathrm{CO}_{2}$. Amonia yang terbentuk sebagian digunakan oleh mikroba untuk membentuk protein tubuhnya dan sebagian lain dibawa ke hati melalui vena porta dan diubah menjadi urea (Wallace, 1991). Urea yang terbentuk dapat masuk kembali ke dalam rumen lewat saliva dan dinding rumen atau akan dikeluarkan lewat urine (McDonald et al., 1988; Reynolds, 1995). Absorpsi $\mathrm{NH}_{3}$ melalui dinding rumen dipengaruhi oleh konsentrasi $\mathrm{NH}_{3}$ dan $\mathrm{pH}$ rumen. Absorpsi akan meningkat sejalan dengan meningkatnya konsentrasi $\mathrm{NH}_{3}$ dalam rumen dan menurun bila $\mathrm{pH}$ rumen rendah (Owens dan Zinn, 1988).

Produksi $\mathrm{N}$ mikrobia yang tertinggi $(5.28 \mathrm{mg} / 100 \mathrm{ml})$ dicapai oleh T5 (BKUM1:7) dan sangat nyata $(\mathrm{P}<0.01)$ dibandingkan dengan perlakuan yang lain. Sehingga pada tingkat produksi VFA dan konsentrasi $\mathrm{NH}_{3}$ yang setara, ternyata terjadi perbedaan pada produksi $\mathrm{N}$ mikrobia. Jadi produksi $\mathrm{N}$ mikrobia lebih ditentukan oleh sinkronisasi penyediaan energi (VFA) dan sumber $\mathrm{N}\left(\mathrm{NH}_{3}\right) . \mathrm{NH}_{3}$ yang terbentuk dari proses deaminasi asam amino dikombinasikan dengan asam organik alfa keto menjadi asam amino baru sebagai prekursor untuk sintesis $\mathrm{N}$ mikroba. Ternak yang mendapatkan pakan basal berserat kasar tinggi, produksi mikroba dalam rumen dibatasi oleh ketersediaan energi, protein mudah larut dan mineral terutama S dan $\mathrm{P}$ (Chuzaemi, 1994). Sauvant et al, (1997) melaporkan bahwa sintesis protein mikroba akan optimal bila pelepasan prekursor $\mathrm{N}$ dan kerangka karbon dalam rumen yang dibutuhkan oleh mikrobia selaras atau sinkron.

\section{KESIMPULAN}

Pakan suplemen yang mengandung urea dan molases pada perbandingan 1:7 dan bungkil kedelai sebagai sumber bypass protein memberikan hasil yang terbaik ditinjau dari kondisi lingkungan rumen dan produksi $\mathrm{N}$ mikrobia rumen.

\section{DAFTAR PUSTAKA}

Anonimous. 2004. Petunjuk Praktikum Biokimia Nutrisi. Laboratorium Biokimia Nutrisi, Jurusan Nutrisi dan Makanan Ternak. Fakultas Peternakan, UGM, Yogyakarta.

Association of Official Analysis Chemist. 1980. Official methods of analysis of the Association of Official Analytical Chemist. $13^{\text {th }}$ Ed. Association of Official Analytical Chemist, Washington, DC.

Czerkawski, J. W. 1978. Reassesment of efficiency of synthesis of microbial matter in the rumen. J. Dairy Sci. 61:1261-1273.

Djajanegara, A. 1993. Tinjauan ulang mengenai suplemen pada jerami padi. Kumpulan Makalah Seminar. Pemanfaatna Limbah Pertanian untuk Makanan Ternak. Lembaga Kimia Nasional dan LIPI, Bandung.

Erwanto, T. Sutardi, D. Sastradipradja dan M.A. Nur. 1993. Effects of ammoniated zeolite on metabolic parameters of rumen microbes. Indon. J. Trop. Agric. 5(1):5.

Faria, V.P. dan J.T. Huber 1984. Effect of dietary protein and energy level on rumen fermentation in holstein steers. J. Anim. Sci. 58: 452 - 458.

Grovum, W. L. 1988. Appetite Palatability And Control Of Feed Intake. In: D. C. Church (Ed). The Ruminant Animal Digestive Physiology and Nutrition. Prentice Hall, Englewood Cliifs. New Yersey. Pp. $201-216$.

Kerley , M.S., G.S. Fahey, J.R., L.L. Berger dan N.R. Merchen. 1987. Effects of treating wheat straw with $\mathrm{pH}$ regulated solution alkaline hydrogen peroxide on nutrient 
digestion by sheep. J. Dairy Sci. 70: $2078-2084$.

Lechner-Doll, M., I.D. Hume dan R.R. Hofmann. 1995. Comparison of herbivore forage selection and digestion. In : M. Journet, E. Grenet, M-H. Farce,, M. Theriez, C. Demarquilly (Eds), Recent Development in the Nutrition of Herbivores. Proc. International, INRA. Paris. Pp. $231-248$.

Leng, R.A. 1980. Principle and Practice of Feeding Tropical Crop and by Products to Ruminant. Department of Biochemistry and Nutrition. University of New England. Armidale, Australia.

McDonald, P., R.A. Edward dan J.F.D. Greenhalgh. 1988. Animal Nutrition. $4^{\text {th }}$ edition. English Language Book Society, Longman, London.

Menke, K.H. dan H. Steingass, 1979. The estimation of the digestibility and metabolizable energy content of ruminant feedingstuffs from the gas production when they are incubated with rumen liquor in vitro. J. of Agric. Sci. 93: 217-222.

Ørskov, E.R. 1992. Protein Nutrition in Ruminants. Second edition. Academic Press, London.

Owens, F. N. dan A. L. Goestch.1988. Ruminant Fermentation. In : D. C. Church (Ed). The Ruminant animal digestive Physiology and Nutrition. Prentice Hall, Englewood Cliifs. New Yersey. Pp. 145 - 171.

Pitt, R. E, J. S. Van Russel, D. G. Fox, A. N. Pell, M. C. Barry dan P. J. Van Soest. 1996. Prediction of ruminal volatile fatty acids and $\mathrm{pH}$ within the net carbohidrat and protein system. J. Anim. Sci. 74: 226 - 244.

Reynold, C.K. 1995. Quantitative Aspects of Liver Metabolism in Ruminant. In : Engelhards, W.V.S. Leonhard Marek, G. Breves, D. Giesecke
(Eds.), Ruminant Physiology : Digestion, Metabolism, Growth and Reproduction. Ferdinant Enke Verlag. Pp. $351-368$.

Satter, L.D. dan L.L. Slyter 1974. Effect of ammonia concentration on rumen microbial production in vitro. $\mathrm{J}$. Nutr. 32: 194.

Sauvant, D dan J. van Milgen. 1995. Dynamic aspects of carbohydrate and protein breakdown and the associated microbial matter synthesis. In : Ruminant Physiology : Digestion, Metabolism, Growth and Reproduction (Engelhardt et al, Ed). Proc. of the eight International Symposium on Ruminant Physiology. Stuttgart Germany. 7187.

Soebarinoto, S. Chuzaemi dan Mashudi. 1991. Ilmu Gizi Ruminansia. Fakultas Peternakan Universitas Brawijaya, Malang.

Soejono M., B. P. Widyobroto, R. Utomo dan A. Agus. 1998. Standardisasi pengukuran degradasi in sacco di Indonesia. Laporan Penelitian Hibah Bersaing VII Perguruan Tinggi. Fakultas Peternakan UGM, Yogyakarta.

Sutardi, T. 1978. Ikhtisar Ruminologi. Departemen Ilmu Makanan Ternak, Fakultas Peternakan IPB, Bogor.

Sutardi, T. 1979. Ketahanan protein bahan makanan terhadap degradasi oleh mikroba rumen dan manfaatnya bagi peningkatan produktivitas ternak. Proc. Seminar Penelitian dan Penunjang Pengembangan Peternakan. Lembaga Penelitian Peternakan Badan Penelitian dan Pengembangan Pertanian, Bogor, 5 - 8 Nopember 1979. Hal $91-103$.

Sutardi, T. 1991. Landasan Ilmu Nutrisi I. Departemen Ilmu Nutrisi dan Makanan Ternak, Fakultas Peternakan IPB, Bogor. 
Tillman, A.D. H. Hartadi, S. Microbial Ecosystem. Elsevier Reksohadiprodjo, S. Prawirokusumo dan S. Lebdosoekojo. 1986. Ilmu Makanan Ternak Dasar. Gadjah Mada University Press, Yogyakarta.

Applied Sci., New York. Pp. $241-$ 249.

Widyobroto B.P., S. Padmowijoto dan R. Utomo. 1997. Pendugaan kualitas protein 60 bahan pakan untuk ternak ruminansia. Laporan Penelitian. Fakultas Peternakan UGM, Yogyakarta. Metabolism ff Nitrogen Containing Compounds In : P.N. Hobson (Ed.), The Rumen 